\title{
The Autolysis of Clostridium sporogenes
}

\author{
By ENRICA GALLI* AND D. E. HUGHES † \\ Medical Research Council Unit for Research in Cell Metabolism, \\ Biochemistry Department, University of Oxford
}

(Received 26 November 1964)

\begin{abstract}
SUMMARY
Washed Clostridium sporogenes lysed during storage at $2^{\circ}$ or on incubation at $37^{\circ}$ in various buffered salt solutions. The lysis was accompanied by a marked increase in adenosine triphosphatase activity (ATPase), due to an enzyme bound to the cytoplasmic membrane. The lysis in buffered salt solutions was most rapid in young vegetative organisms and negligible in organisms from cultures incubated for $30 \mathrm{hr}$. No lysis occurred when organisms were incubated in buffered sucrose, but young organisms formed spheroplasts under these conditions. Both young and older organisms incubated in sucrose lysed when diluted in water. After lysis the residue of older organisms appeared structurally similar to cell-wall membranes prepared by crushing the organisms. Organisms incubated in EDTA or salt solutions containing sulphydryl compounds did not lyse during the incubation or on subsequent dilution with water. It is suggested that lysis was mainly due to changes in the composition or structure of the cell wall and not to alterations in the protoplasmic membrane.
\end{abstract}

\section{INTRODUCTION}

The lysis of bacteria can occur without the addition of a lytic agent either in the growth medium or after separation from it. Such autolysis may be preceded by the formation of rounded osmotically sensitive forms (spheroplasts or protoplasts; McQuillen, 1960), but often the organisms may lyse without spheroplast formation (Collins, 1964). In either case, the autolysis is associated with changes in the cell wall leading to loss of rigidity when spheroplasts are formed or a change in association of the cell wall and the permeability barrier when they are not formed (Collins, 1964). The present work is concerned with factors which control the autolysis of Clostridium sporogenes which occurred after collecting, washing and storing the organisms in various buffered media. Lysis was followed by measuring the release of cell components and estimating the activity of a membrane-bound ATPase which is apparently inactive in intact organisms owing to impermeability to ATP.

\section{METHODS}

Growth and handling of organisms. The organism used was a strain of Clostridium sporogenes isolated from mouse intestinal microflora and characterized by its ability to utilize cholesterol (Galli \& Carini, 1962). It was maintained and grown on

* N.A.T.O. Science Fellow, Istituto di Microbiologia Generale Agraria e tecnica, Universita di Milano, Italy.

$\dagger$ Present address: Microbiology Department, University College, Cardiff. 
the following medium: Oxoid tryptone, $20 \mathrm{~g}$; Oxoid yeast extract, $6 \mathrm{~g}$; glucose, $20 \mathrm{~g}$; ; sodium acetate, $10 \mathrm{~g}$.; $\mathrm{KH}_{2} \mathrm{PO}_{4}, 4.5 \mathrm{~g}$.; ascorbic acid, $1 \mathrm{~g}$.; salt $\mathrm{B}$ solution (BartonWright, 1952), $5 \mathrm{ml}$. The components were dissolved in 11 . water and adjusted to $\mathrm{pH} 7 \cdot 6$ with $\mathrm{NaOH}$. Usually $10 \mathrm{l}$. batches were grown in 101 . narrow-necked Pyrex bottles filled to the top with the medium and autoclaved for $10 \mathrm{~min}$. at $115^{\circ}$. After incubation at $37^{\circ}$ the organisms were collected by centrifugation and washed once in a solution containing $0.9 \%(\mathrm{w} / \mathrm{v}) \mathrm{NaCl}$ and $0.2 \mathrm{M}$-tris + maleate buffer $(\mathrm{pH} \mathrm{7 \cdot 0)}$. The organisms were resuspended, packed by centrifugation for $30 \mathrm{~min}$. at $8000 \mathrm{~g}$ and then suspended smoothly in a suitable medium by the aid of a Konte's type glass homogenizer (Konte's Glass Works, Vineland, New Jersey, U.S.A.) to contain the equivalent of $\mathbf{0} \cdot \mathbf{1} \mathrm{g}$. dry wt. organisms $/ \mathrm{ml}$.

Estimations of lysis. Suitable volumes of the above suspension of organisms were placed in the medium to be studied, in glass-stoppered tubes. To follow lysis, samples were taken at intervals and their extinction measured at $540 \mathrm{~m} \mu\left(E_{540}\right)$ in a Unicam SP600 spectrophotometer. The extinction was expressed as

$$
\frac{E_{540} \text { initial }-E_{540} \text { final }}{E_{540} \text { initial }} \times 100
$$

and is referred to as ' $\%$ lysis'. Samples were prepared at the same time for light microscopy and examined immediately by phase contrast or fixed by heat and stained by Gram's method. Samples for electron microscopy were fixed in Palade buffered osmium solution (Palade, 1952), washed twice with water and mounted on Formvar covered grids. The grids were examined at magnifications of $\times 600-17000$ in the Akashi Tronoscope. When the release of components from organisms to the suspending fluid was to be measured the samples were centrifuged at $2^{\circ}$ for 15 $20 \mathrm{~min}$, at $18,000 \mathrm{~g}$ and the component estimated in the clear supernatant fluid.

Chemical estimations. Protein was estimated with the Folin-Ciocalteau reagent (Lowry, Rosebrough, Farr \& Randall, 1951); total carbohydrate by the method of Dische \& Shettles (1948); deoxyribonucleic acid by the method of Burton (1956) and ribonucleic acid by the method of Mejbaum (1939). Lipid was extracted from preparations, which had been dried from the frozen state, with methanol+chloroform $\left(2+1\right.$ by vol.), the extract washed with water, dried over $\mathrm{Na}_{2} \mathrm{SO}_{4}$, evaporated to dryness under a stream of nitrogen, dried in vacuo over paraffin wax, and the residue weighed. The lipid residue was redissolved in chloroform and the total $\mathbf{P}$ estimated for after ashing in a perchloric + sulphuric acid mixture $(2+1$ by vol.) by the method of Fiske \& SubbaRow (1925). All constituents are expressed as mg./mg. dry wt. organisms estimated after drying a sample at $110^{\circ}$ to constant weight, and subtracting the dried weight of the suspending medium.

Estimation of enzyme activity. The activity of ATPase was estimated by assuming that ATP is hydrolysed according to the reaction $\mathrm{ATP}+\mathrm{H}_{2} \mathrm{O} \rightarrow \mathrm{ADP}+\mathrm{H}_{3} \mathbf{P O}_{4}$. Usually $0.1 \mathrm{ml}$. of the cell preparation was incubated at $37^{\circ}$ in a mixture containing ATP $1.0 \mu$ mole, $0.5 \mathrm{ml}$. $0 \cdot 2 \mathrm{M}$-tris + maleate buffer $(\mathrm{pH} 7 \cdot 0), \mathrm{MgCl}_{2} 1.0$ mole; in total vol. $1.0 \mathrm{ml}$. After incubation the tubes were placed in ice, cooled to $2^{\circ}$, and $1.0 \mathrm{ml}$. cold $5 \%(\mathrm{w} / \mathrm{v})$ perchloric acid added. The tubes were centrifuged and phosphate estimated in $0.5 \mathrm{ml}$. of the supernatant fluid by the method of Fiske \& SubbaRow (1925). 


\section{RESULTS}

\section{Lysis of stored suspensions of organisms}

Suspensions of organisms which had been incubated for 16 to $24 \mathrm{hr}$ were stored in $0.2 \mathrm{M}$-tris + maleate buffer $(\mathrm{pH} 7 \cdot 0)$ containing $0.9 \%(\mathrm{w} / \mathrm{v}) \mathrm{NaCl}$ at $2^{\circ}$ for periods up to 7 days, during which time they became very viscous. The viscosity was rapidly decreased by the addition of crystalline DNase ( $1 \mathrm{mg} . / 100 \mathrm{ml}$. suspension), and was presumably due to the release of DNA from the organisms. After treatment with DNase the suspension was centrifuged for $30 \mathrm{~min}$. at 28,000g. The supernatant fluid contained the bulk of the cell protein DNA and RNA. The solid residue contained high ATPase activity (Table 1) and in the electron microscope was similar in appearance to cell-wall membrane preparations obtained by crushing fresh organisms in the Hughes press and treatment with DNase (Hunt, Rodgers \& Hughes, 1959). In the light microscope by phase contrast the organisms appeared to be little changed, but when stained by Gram's method most organisms were Gramnegative, instead of Gram-positive as at the beginning of the storage period. There was no apparent formation of spheroplasts at any time in such suspensions. A similar but more rapid lysis was observed when the suspensions were incubated at $37^{\circ}$ : complete lysis occurred in 16-18 hr. Most of the subsequent experiments were done at $37^{\circ}$.

Table 1. Lysis of Clostridium sporogenes vegetative forms and corresponding ATPase activity

\begin{tabular}{|c|c|c|}
\hline & $\begin{array}{l}\text { ATPase activity } \\
\text { ( } \mu \text { mole Pi/mg. } \\
\text { dry wt./hr.) }\end{array}$ & $\begin{array}{c}\text { Protein in } \\
\text { supernatant fluid } \\
\text { (mg./mg. dry wt. } \\
\text { organisms) }\end{array}$ \\
\hline Whole fresh organisms & $0 \cdot 10$ & 0.04 \\
\hline Outer shell (by autolysis) & $0 \cdot 30$ & $0 \cdot 20$ \\
\hline Outex shell (by Hughes press) & $0 \cdot 45$ & $0 \cdot 40$ \\
\hline
\end{tabular}

The effect of sucrose on lysis

Suspensions of organisms in concentrations of sucrose from 0.5 to $1.5 \mathrm{M}$ were incubated at $37^{\circ}$ for $18 \mathrm{hr}$. Slight lysis was observed in the lowest concentration but no lysis occurred in $1.0 \mathrm{M}$-sucrose as judged by extinction and protein determinations. However, when such suspensions were diluted with water to decrease the concentration of sucrose below $0.2 \mathrm{M}$, most of the remaining organisms lysed almost immediately. The ATPase of suspensions was negligible before dilution but increased rapidly upon dilution and was equal to that of organisms incubated in the absence of sucrose (Table 2). In the light microscope and in the electron microscope organisms incubated in sucrose appeared to be unchanged, but were found to be empty upon dilution in water (Fig. 1). $\mathrm{NaCl}$ at various concentrations had no effect on lysis. $\mathrm{Na}$ ethylenediaminetetra-acetate (EDTA, 500 $\mu \mathrm{g} . / \mathrm{ml}$.) inhibited lysis completely. Organisms incubated with EDTA did not lyse on dilution in water nor did their 
ATPase activity increase. The addition of $\mathrm{CaCl}_{2}, \mathrm{MgCl}_{2}, \mathrm{MnCl}_{2}$ (all $0.01 \mathrm{M}$ ) as well as EDTA allowed lysis to proceed (Table 3).

\title{
The effect of sylphydryl compounds on lysis
}

The addition of cysteine, mercapto-acetate, aminoethylthiouronium chloride (AET) or mercapto-ethanol to the incubation mixture in concentrations from 0.05 to $0.004 \mathrm{M}$ slowed or prevented the lysis (Table 4). In the optimum mercaptoacetate concentration $(0.02 \mathrm{M})$ organisms appeared to be unchanged microscopically

\section{Table 2. The effect of sucrose concentration on lysis of stored organisms}

\begin{abstract}
Washed suspensions of Clostridium sporogenes vegetative forms were suspended in $0 \cdot 2 \mathrm{M}$-tris + maleate buffer $\mathrm{pH} 7 \cdot 0$ with or without sucrose as indicated. After incubation at $37^{\circ}$ for $18 \mathrm{hr}$ the organisms were separated by centrifugation and the ATPase activity of a portion estimated as usual (before dilution), and the protein content of the supernatant was also estimated. Another portion of the organisms was suspended in water, centrifuged, and the ATPase activity of the solid and the protein content of the supernatant estimated (after dilution). Control was not incubated.
\end{abstract}

\begin{tabular}{|c|c|c|c|c|}
\hline \multirow{2}{*}{$\begin{array}{l}\text { Sucrose } \\
\text { conch. } \\
\text { (molar) }\end{array}$} & \multicolumn{2}{|c|}{$\begin{array}{c}\text { ATPase activity } \\
(\mu \mathrm{mole} \mathrm{Pi} / \mathrm{mg} . \text { dry wt. } \\
\text { organisms } / \mathrm{hr})\end{array}$} & \multicolumn{2}{|c|}{$\begin{array}{l}\text { Protein in supernatant } \\
\text { (mg./mg. dry wt. } \\
\text { organisms) }\end{array}$} \\
\hline & $\begin{array}{l}\text { Before } \\
\text { dilution }\end{array}$ & $\begin{array}{c}\text { After } \\
\text { dilution }\end{array}$ & $\begin{array}{c}\text { Before } \\
\text { dilution }\end{array}$ & $\begin{array}{c}\text { After } \\
\text { dilution }\end{array}$ \\
\hline Control & $0.20-0.10$ & - & $0.04-0.08$ & - \\
\hline None & $0.50-0.35$ & 0.58 & $0 \cdot 19-0 \cdot 81$ & - \\
\hline 0.5 & 0.22 & 0.62 & $0 \cdot 10$ & 0.25 \\
\hline 0.75 & $0 \cdot 13$ & 0.43 & $0 \cdot 19$ & 0.30 \\
\hline $1 \cdot 0$ & 0.05 & $0 \cdot 30$ & $0 \cdot 11$ & 0.20 \\
\hline $1 \cdot 5$ & $0 \cdot 17$ & 0.54 & $0 \cdot 10$ & 0.20 \\
\hline
\end{tabular}

Table 3. The effect of EDT $A$ and metal ions on lysis of organisms

\begin{abstract}
Washed suspensions of Clostridium sporogenes were suspended in $0.2 \mathrm{M}$-tris + maleate containing $0.9 \%(\mathrm{w} / \mathrm{v}) \mathrm{NaCl}$ and the addition shown below. After $18 \mathrm{hr}$ at $38^{\circ}$ the suspension was centrifuged and suspended in buffer. ATPase activity was estimated in a portion (before dilution) and another portion was diluted in 10 vol. water, centrifuged and ATPase estimated in the solid residue (after dilution). Percentage lysis was estimated as described in the text.
\end{abstract}

\section{Addition}

EDTA $(500 \mu \mathrm{g} . / \mathrm{ml}$.

EDTA $(500 \mu \mathrm{g} . / \mathrm{ml}$.) and $0.01 \mathrm{~m}$ -

$\mathrm{MgCl}_{2}$ or $-\mathrm{MnCl}_{2}$ or $-\mathrm{CaCl}_{2}$
ATPase activity ( $\mu$ mole Pi/mg. dry wt. organisms/hr)

$\begin{array}{cc}\begin{array}{c}\text { Before } \\ \text { dilution }\end{array} & \begin{array}{c}\text { After } \\ \text { dilution }\end{array} \\ 0.17 & 0.26 \\ 0.55 & 0.64\end{array}$

after incubation at $37^{\circ}$ for $18-20 \mathrm{hr}$ and even after dilution in water the organisms appeared normal. There was no increase in ATPase activity in organisms incubated with the sulphydryl compounds and then diluted in water; surprisingly, mercaptoethanol did not affect lysis. There was no marked difference between organisms shaken and incubated in wide flasks exposed to the air or in narrow sealed tubes. Likewise collecting and washing the organisms in media containing SH-compounds 
or rigid exclusion of oxygen by nitrogen during collection, washing and incubation, made no difference to the rate of lysis. The protective effect of SH-compound therefore did not appear to be simply due to effects of oxygen on this strict anaerobe.

\section{The effect of age of culture on lysis}

Cultures of Clostridium sporogenes were harvested at different times corresponding to the late lag $(4 \mathrm{hr})$, exponential growth (8-12 hr) and stationary (12-30 hr) phase of growth, and their lysis followed by extinction and microscopic examinations under the usual conditions when suspended in buffer alone, buffer + sucrose, or buffer + mercapto-acetate. In buffer alone the lysis was greater in the youngest organisms and least in the oldest, in fact organisms harvested at $30 \mathrm{hr}$ did not lyse

\section{Table 4. The effect of sulphydryl compounds on lysis of organisms}

\begin{tabular}{|c|c|c|c|}
\hline \multirow[b]{2}{*}{ Sulphydryl compounds } & \multirow[b]{2}{*}{$\begin{array}{c}\text { Lysis } \\
(\%)\end{array}$} & \multicolumn{2}{|c|}{$\begin{array}{c}\text { ATPase activity } \\
\text { ( } \mu \text { mole Pi/mg. dry wt. } \\
\text { organisms } / \mathrm{hr})\end{array}$} \\
\hline & & $\begin{array}{c}\text { Before } \\
\text { dilution }\end{array}$ & $\begin{array}{l}\text { After dilution } \\
\text { in water }\end{array}$ \\
\hline Cysteine $(0.02 \mathrm{M})$ & $\mathbf{0}$ & $0 \cdot 15$ & $\mathbf{0} \cdot \mathbf{2 0}$ \\
\hline Mercapto-ethanol $(0 \cdot 02 \mathrm{M})$ & 60 & 0.40 & $0 \cdot 36$ \\
\hline Aminoethylthiouronium chloride $(0 \cdot 2 \mathrm{M})$ & $\mathbf{0}$ & $\mathbf{0} \cdot 13$ & $0 \cdot 20$ \\
\hline Mercapto-acetate $(0.02 \mathrm{M})$ & 0 & $0 \cdot 17$ & $\mathbf{0 \cdot 2 4}$ \\
\hline Mercapto-acetate $(0.05 \mathrm{M})$ & 0 & 0.04 & $0 \cdot 15$ \\
\hline Mercapto-acetate $(0.004 \mathrm{M})$ & 70 & 0.56 & $0 \cdot 40$ \\
\hline
\end{tabular}

Table 5. The effect of time of harvesting organisms on lysis

Clostridium sporogenes vegetative forms were harvested from the culture medium at the times indicated, incubated in $0.02 \mathrm{~m}$-tris + maleate buffer, $\mathrm{pH} 7 \cdot 0$, for $18 \mathrm{hr}$ and lysis followed by measuring the extinction.

$\begin{array}{cccc}\begin{array}{c}\text { Time of } \\ \text { harvesting } \\ \text { (hr) }\end{array} & \begin{array}{c}\text { Buffer } \\ \text { alone }\end{array} & \begin{array}{c}\text { Buffer }+ \\ \text { sucrose (M) } \\ \text { Lysis (\%) }\end{array} & \begin{array}{c}\text { Buffer+0.02 M } \\ \text { mercapto-acetate }\end{array} \\ 4 & 86 & 20 & 0 \\ 8 & 92 & 20 & 0 \\ 12 & 64 & 20 & 0 \\ 16 & 58 & 18 & 0 \\ 30 & 15 & 6 & 0\end{array}$

appreciably during incubation for $18 \mathrm{hr}$ (Table 5). In buffered sucrose, the youngest organisms (4- $-8 \mathrm{hr}$ ) slowly lysed but this was accompanied by the appearance of some spheroplasts (Fig. 2). The older organisms (18-30 hr) did not show such spheroplast formation. The spheroplasts from young organisms in buffer + sucrose lysed instantly when diluted in water, leaving typical 'ghost' forms (Fig. 3). In the electron microscope most of the spheroplasts from young organisms appeared to be empty even before dilution in water. This was because they lysed upon the addition 
of fixative, no satisfactory way was found to preserve them. In contrast, apparently unlysed organisms and older organisms upon dilution formed cell-wall membranes (Fig. 4). Both young and older organisms incubated in buffered mercapto-acetate $(0.03 \mathrm{M})$ remained intact, as judged microscopically, by extinction and protein determinations (Table 6).

Table 6. The effect of harvest time of organisms on the rate of lysis

Clostridium sporogenes was harvested at the times indicated and the organisms incubated at $37^{\circ}$ in $0.2 \mathrm{M}$-tris + maleate, $\mathrm{pH} 7 \cdot 0$ with additions as indicated. Lysis was followed by measuring $E_{540}$

Time of
harvesting (hr)

4

8

16

\section{Addition}

\section{None}

Sucrose (M)

Buffer + mercapto-acetate (0.02M)

\section{None}

Sucrose (M)

Mercapto-acetate (0.02M)

None

Sucrose (M)

Mercapto-acetate $(0.02 \mathrm{M})$
Time of incubation

\begin{tabular}{|c|c|c|c|}
\hline $2 \mathrm{hr}$ & $4 \mathrm{hr}$ & $8 \mathrm{hr}$ & $18 \mathrm{hr}$ \\
\hline \multicolumn{4}{|c|}{$\%$ lysis } \\
\hline 92 & 92 & 92 & 92 \\
\hline 10 & 16 & 20 & 40 \\
\hline 0 & o & 0 & 0 \\
\hline 76 & 96 & 96 & 96 \\
\hline 6 & 8 & 10 & 25 \\
\hline 0 & 0 & $\mathbf{0}$ & 0 \\
\hline 2 & 4 & 4 & 54 \\
\hline 2 & 2 & 2 & 25 \\
\hline 0 & 0 & 0 & 0 \\
\hline
\end{tabular}

Table 7. Relation of period of incubation of cultures to ATPase activity during lysis

Clostridium sporogenes was harvested, suspended in $0 \cdot 2 \mathrm{M}$-tris + maleate, $\mathrm{pH} 7 \cdot 0$, with additions as indicated. Their ATPase activity was estimated in the presence of $M$-sucrose in the incubation mixture after incubation at $37^{\circ}$. Enzyme activities were also estimated after dilution in water.

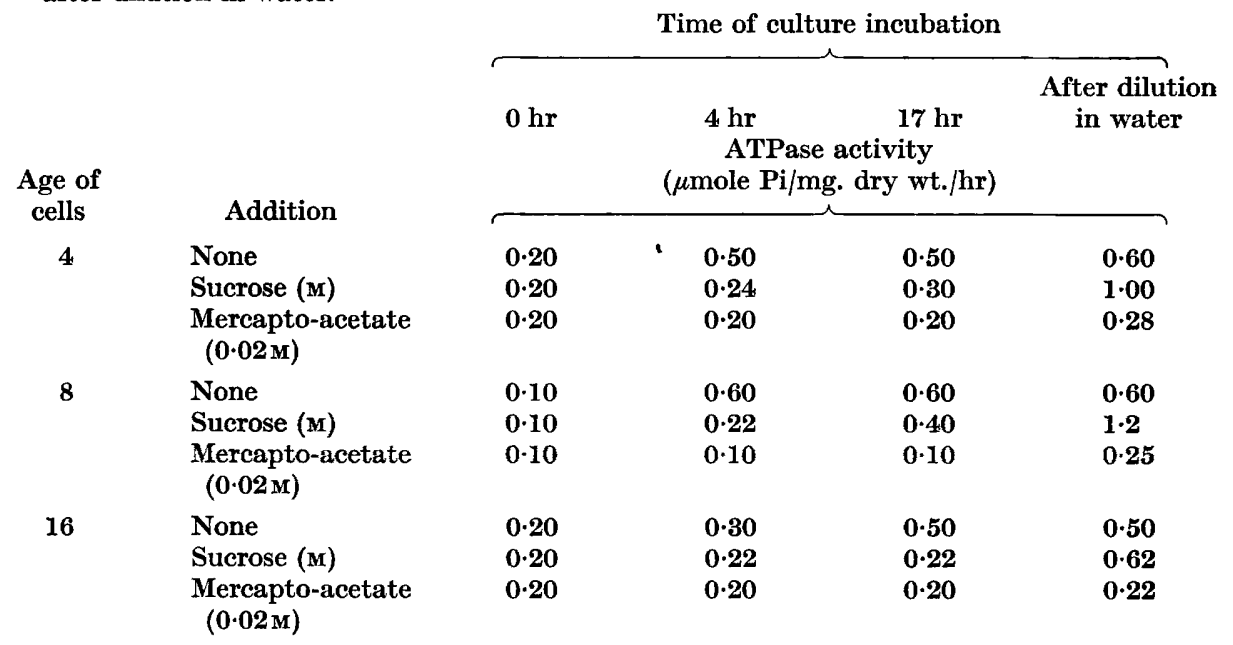

In following the ATPase of young cultures it was found that many batches lysed in less than $20 \mathrm{~min}$. in the enzyme assay incubation mixture, this was completely prevented by the addition of sucrose (to $1 \cdot 0 \mathrm{M}$ ). There was no apparent effect of 
sucrose on ATPase activity. With sucrose in the incubation mixture the ATPase activity with young and old organisms paralleled the results of microscopic examination, in showing that in young and rapidly growing organisms the changes which preceded lysis took place rapidly, whereas in the older organisms this process became progressively slower (Table 7).

\section{Table 8. The chemical composition of fractions of Clostridium sporogenes}

Preparations of the solid residues of cells crushed in the Hughes press and after autolysis were prepared by centrifugation for $20 \mathrm{~min}$ at $30000 \mathrm{~g}$ and washing twice in $0.2 \mathrm{M}-$ tris + maleate buffer, $\mathrm{pH} \mathbf{7 \cdot 0}$. Dry weights were determined on samples. Protein and other constituents were determined as follows. Protein (Lowry et al. 1951), carbohydrate (Dische \& Shettles, 1948), DNA (Burton, 1956), RNA (Mejbaum, 1939). Values are expressed in terms of dry wt. of organisms after subtracting the contribution due to the suspending medium.

\begin{tabular}{|c|c|c|c|c|}
\hline Sample & $\begin{array}{l}\text { Protein } \\
\text { (mg./mg. } \\
\text { dry wt.) }\end{array}$ & $\begin{array}{c}\text { RNA } \\
(\mu \mathrm{mole} \\
\text { ribose/mg. } \\
\text { dry wt. })\end{array}$ & $\begin{array}{c}\text { DNA } \\
(\mu \text { mole } \\
\text { deoxyribose } / \\
\text { mg. dry wt. })\end{array}$ & $\begin{array}{c}\text { Total } \\
\text { carbohydrate } \\
\text { (mg./mg. } \\
\text { dry wt.) }\end{array}$ \\
\hline & $0 \cdot 32$ & $0 \cdot 10$ & - & $0 \cdot 12$ \\
\hline Iughes press) & $0 \cdot 25$ & $0 \cdot 10$ & $0 \cdot 17$ & 0.063 \\
\hline Lughes press) & $0 \cdot 60$ & 0.49 & $\mathbf{0 \cdot 3 0}$ & $0 \cdot 039$ \\
\hline utolysis in buffer) & $0 \cdot 30$ & 0.08 & 0.07 & 0.019 \\
\hline autolysed cells) & 0.50 & 0.47 & $0 \cdot 20$ & 0.037 \\
\hline
\end{tabular}

\section{Chemical analysis of cell fractions}

The solid and supernatant fractions from cell-wall membranes prepared in the Hughes press and those prepared by lysis appeared similar in the chemical composition of most of the fractions analysed except that the total carbohydrate in lysed preparations was much lower than those from the press (Table 8). Both solid preparations contained about 6-8\% total lipid of which the bulk was phospholipid as indicated by a figure of 3-4\% inorganic phosphate after ashing. Fractions of the lipid were esterified and examined by gas chromatography. There appeared to be no major difference in the distribution of fatty acids between the two types of preparations.

\section{DISCUSSION}

The work reported in this paper started with the observation that Clostridium sporogenes vegetative forms with a low initial ATPase activity increased in activity upon storage at $2^{\circ}$ in various salt solutions. A similar but less marked increase had previously been seen with preparations of certain lactobacilli (Cole \& Hughes, 1965). Experiments with crushed $C$. sporogenes and $C$. welchii confirmed that, as with all other bacteria so far tested, the ATPase was located in the protoplasmic membrane (Hughes, 1962). It seemed therefore that the increase of ATPase activity upon storage might be explained by an increase in the permeability of the membrane which is normally impermeable to ATP. Such changes can be caused by the addition of cationic detergents to whole cells ( DrV. Knivett, personal communication). However, further experiments suggest that the membrane probably remains intact until changes occur in the cell-wall which render the cell extremely sensitive to osmotic shock. This idea is supported by the finding that organisms incubated in sucrose solutions neither lyse nor increase in ATPase activity. Subsequent dilution 
of such organisms in water results in immediate lysis and increase in ATPase activity. Microscopic examination showed organisms of normal appearance after incubation in sucrose but on dilution in water they emptied to produce typical empty cell walls. The ATPase and phospholipid were associated with the cell wall; for this reason the preparation is considered to be similar to cell-wall membranes prepared by disintegrating cells in the Hughes press (Hunt et al. 1959) or in the French press (Dr. J. Wimpenny, personal communication). The younger organisms produced rounded forms in sucrose; these lysed on dilution in water and are therefore referred to as 'spheroplasts'. Lysis associated with spheroplast formation could be explained by changes in cell-wall structures associated with the 'rigid layer' (Weidel, Frank \& Martin, 1960). In the older organisms lysis however appeared not be be accompanied by such changes in the rigidity of the wall. A similar lysis without spheroplast formation has recently been reported by Collins (1964) and by Voss (1964). It is possible that this type of lysis may be due to a loosening of the bonding between the wall and the membrane postulated by McQuillen (1958) and Hughes (1962). The lysis discussed by Collins was brought about by a lytic enzyme derived from old organisms and that by Voss was due to lysozyme and EDTA. In both cases the lysis was accompanied by a loss of material from the outer envelopes, presumably the cell wall. Lysis due to deficiencies of cell-wall structures can be produced in growing bacteria by the addition of inhibitors of cell-wall synthesis to the medium (Welsch, 1958) or by the omission of essential cell-wall constituents from the medium (Toennies \& Shockman, 1958). The autolysis of growing cultures may be due to lytic agents of microbial origin such as lysogenic phages (Jacob \& Fuerst, 1958) and colicins (Fredericq, 1958). In stationary cell suspensions lytic enzymes such as those described by Collins (1964) may also produce lysis. The lysis reported here was much more marked when young organisms rather than older ones were incubated in the absence of growth medium. It could thus be explained by the exhaustion of some essential wall component consequent on some growth in the absence of extraneous nutrient medium, and depending on endogenous metabolism. Alternatively the action of lytic enzymes cannot altogether be ruled out despite their not being found in organisms or culture medium. The protection against lysis by EDTA and sulphydryl compounds would tend to support the idea of the second mechanism (see Repaske, 1960; Voss, 1964), since both these agents can modify lysis.

Thanks are due to the Rockefeller Foundation, U.S. National Institutes of Health and United States Air Force for grants to the Department. One of us (E.G.) thanks the NATO Fellowship Foundation for support during the work. Thanks are also due to Dr J. Wimpenny for helpful discussions and to Mrs H. Mitchell and Miss A. West for skilled assistance. 
Journal of General Microbiology, Vol. 39, No. 3

Plate 1

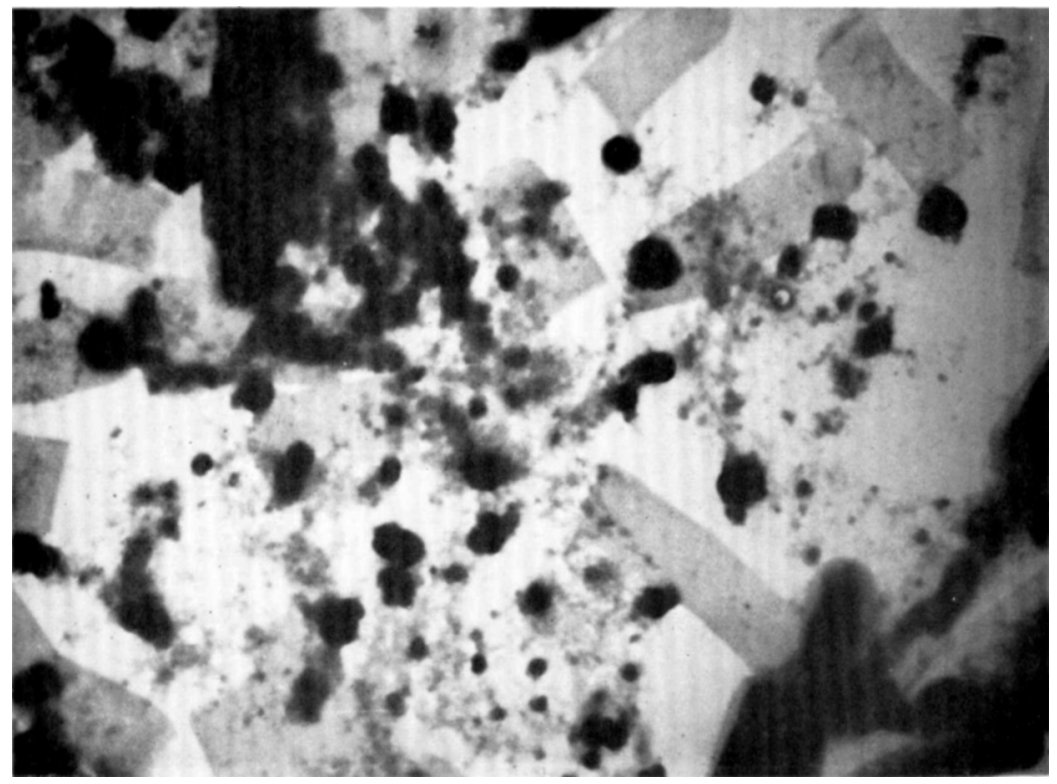

Fig. 1

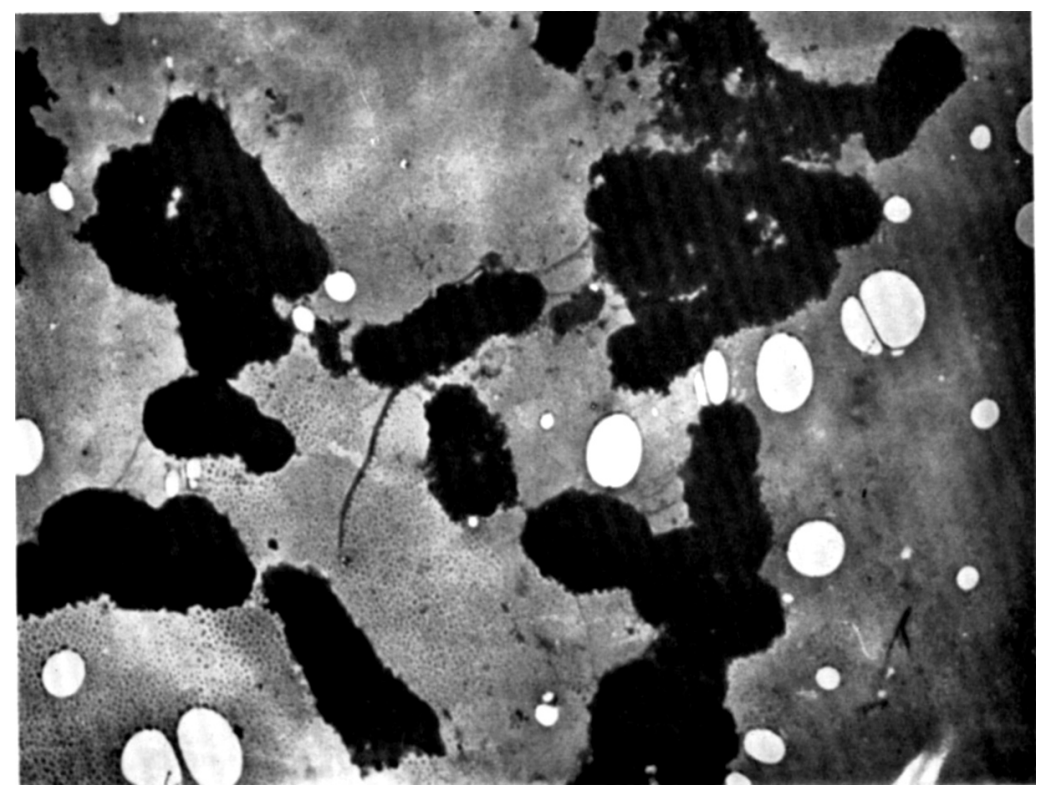

Fig. 2 


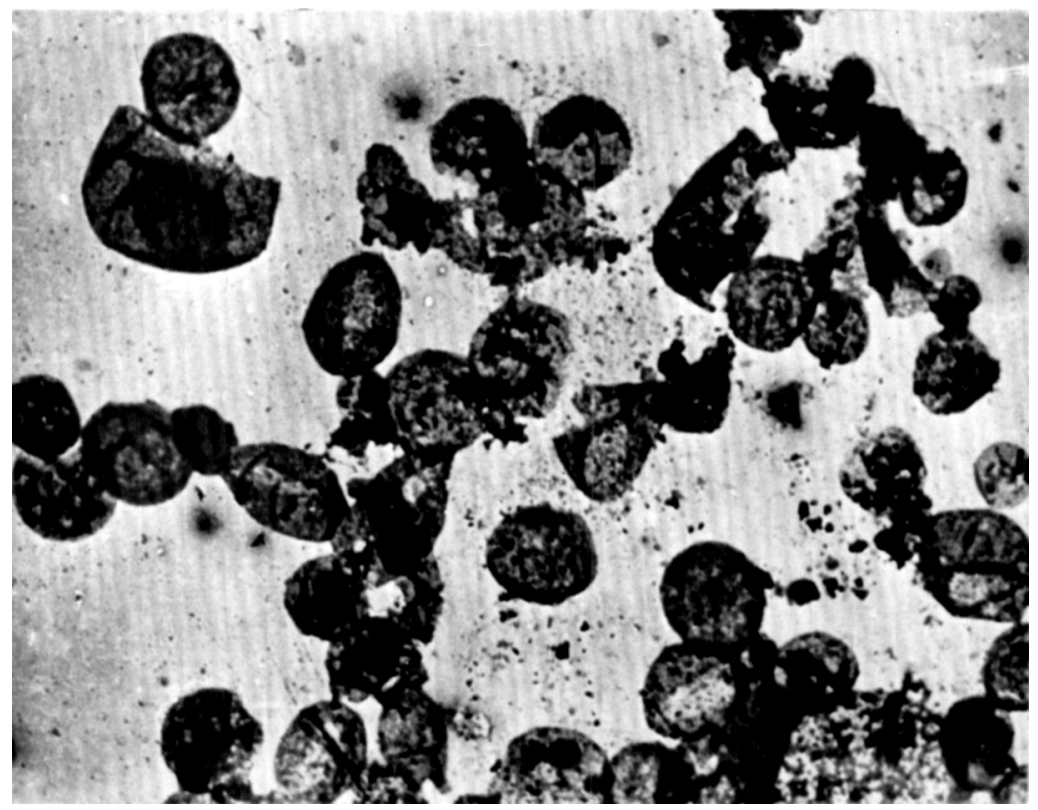

Fig. 3

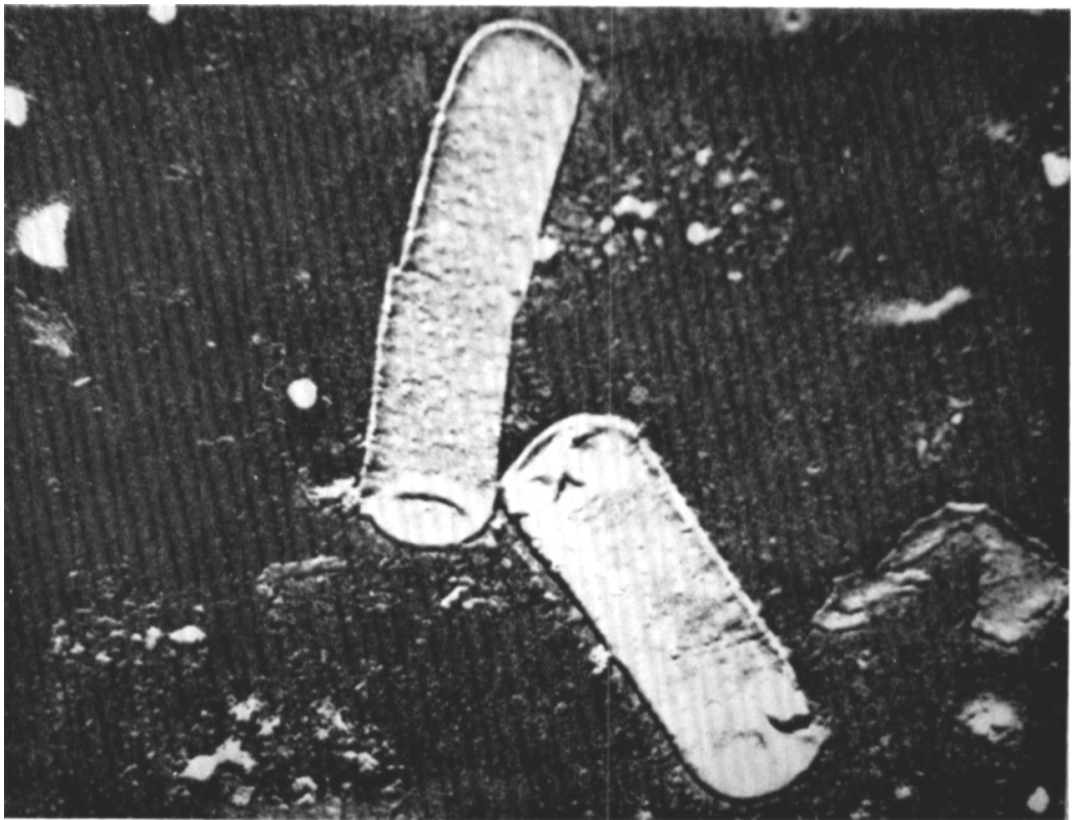

Fig. 4

ENRICA GALLI AND D. F. HUGHES 


\section{REFERENCES}

Barton-Wright, E. C. (1952). The Microbiological Assay of the Vitamin B Complex and Amino Acids. London: Pitman and Sons.

Burton, K. (1956). A study of the conditions and mechanism of the diphenylamine reaction for the colorimetric estimation of deoxyribonucleic acid. Biochem. J. 62, 315.

Cone, H. \& Hughes, D. E. (1965). The enzymic activity of the outer shell of Lactobacillus arabinsus. J. gen. Microbiol. 40, (to be published).

Couriss, F. M. (1964). Composition of cell walls of ageing Pseudomonas aeruginosa and Salmonella bethesda. J. gen. Microbiol. 34, 379.

Dische, Z. \& Shettres, L. B. (1948). A specific colour reaction of methylpentoses and $\dot{a}$ spectrophotometric micro method for their determination. J. biol. Chem. 175, ¿95.

Fiske, C. H. \& SubBaRow, Y. (1925). The colorimetric determination of phosphorus. J. biol. Chem. 66, 375.

FredericQ, P. (1958). Colicins, colicinogenic factors and their relations to bacteriophages. J. gen. Microbiol. 18, 527.

Galli, E. \& Carini, S. (1962). Riduzione del colesterolo in vitro Escherichia coli e Clostridium sporogenes. Rend. Accademia Nazionale dei Lincei, 34, 972.

Hughes, D. E. (1962). The bacterial cytoplasmic membrane. J. gen. Microbiol. 29, 39.

Hunt, A. L., Rodgers, A. \& Hughes, D. E. (1959). Sub-cellular particles and the nicotinic acid hydroxylase system in extracts of Pseudomonas fluorescens. Biochem. biophys. Acta, 34, 354.

JACOB, F. \& Fuerst, C. R. (1958). The mechanism of lysis by phage studied with defective lysogenic bacteria. J. gen. Microbiol. 18, 518.

Lowry, O. H., Rosebrough, N. J., Farr, A. L. \& Randall, R. J. (1951). Protein measurement with the folin phenol reagent. J. biol. Chem. 193, 265.

McQuilles, K. (1958). Some aspects of bacterial structure: observations on bacterial cell walls, protoplasts and spheroplasts. Proc. Int. Congr. Bioch. xIII, 406.

McQuillen, K. (1960). Bacterial protoplasts. In The Bacteria, vol. I, p. 268. Ed. by I. C. Gunsalus \& R. Y. Stanier. New York and London: Academic Press.

Mejbaum, W. (1939). Über die Bestimmung kleiner Pentose Mengen, insbesondere in Derivaten der Adenylsäure. Z. Physiol. Chem. 258, 117.

Palade, G. E. (1952). A study of fixation for electron microscopy. J. exp. Med. 95, 285.

RePaske, R. (1960). Lysozyme as related to problems in microbiology. Symp. of Soc. Amer. Bact., Philadelphia,

Toennies G. \& Shockman, G. D. (1958). Growth chemistry of Streptococcus faecalis. Proc. Int. Congr. Biochem. xIII, 365.

Voss, J. G. (1964). Lysozyme lysis of Gram-negative bacteria without production of spheroplasts. J. gen. Microbiol. 35, 313.

Weidel, W., Frank, H. \& Martin, H. H. (1960). The rigid layer of the cell wall of Escherichia coli strain B. J. gen. Microbiol. 22, 158.

WeLSCH, M. (1958). Lysis by agents of microbial origin. J. gen. Microbiol. 18, 491.

\section{EXPLANATION OF PLATES}

Fig. 1. Empty cells formed by diluting cells. Cells were grown for $18 \mathrm{hr}$, collected and washed, and incubated for $18 \mathrm{hr}$ in sucrose and then diluted in water. $\times 12,000$.

Fig. 2. An early stage of lysis in young cells ( $8 \mathrm{hr}$ growth) incubated in sucrose and showing the start of spheroplast formation. $\times 7,500$.

Fig. 3. Empty spheroplasts, i.e. 'ghosts' formed from young cells $(8 \mathrm{hr})$ incubated for $18 \mathrm{hr}$ in sucrose and diluted in water. $\times 12,000$.

Fig. 4. Cell-wall membranes from crushed cells incubated with DAase but not further treated. Shadowed with Au-Pd. $\times 15,000$. 